\section{研究所紹介シリース 25}

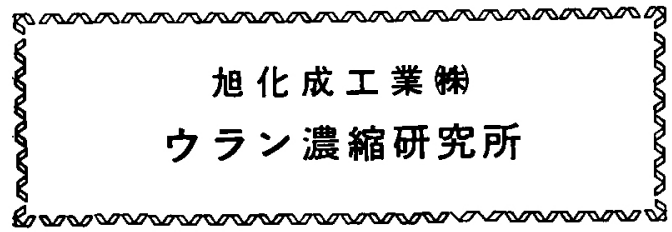

\section{I. 浻革}

当ウラン浱樎研究所は昭和 46年, 東京工業大学原子 妒工学研究所の指導を得た後 47 年, 数名からなる当社 川崎支社での探索研究に始まる。当時, ウラン同位体 間の微小な偏りを示す化学的平術の存在と,それを利 用した化学的ウラン澺樎の可能性を示す学術諭文が知 られているたけけ状況であった。したがって，当初は 化学法に関わる技術全般にわたって原理的検討と実験 による確認が必要であった。このような状況の中か ら、イオン交換体を用いた酸化遥元クロマト法を開発 し，技術的革新とそれに基つく将来見通しが開けるに つれて研究室の体制も次第に整備されていった。

昭和53〜 54年にかけて, 当社の化学交換法の実用可 能性が公的に評価され，55年国庫補助の交付が決定さ れた。これを受けて56年にウラン浱縮研究所の設立に 至った。57年に, 研究規模の拡大に対応して研究所の 本拋地を宮崎県日向市に移転し，川崎には基礎研究部 門を残す体制となった。60年にモデルブラントが完成 し, 現在に至っている。

\section{II . 研究所の概要と研究内容}

研究所には現在, 開発研究, 工学研究, 運転試験, 分 析研究, 保全, 安全管理の 6 担当と, そのほか技術およ び事務管理スタッフが所属している。6 担当の5ち開 発研究担当は川猗にあり，吸着郕製造設備の運転も担 当している。その他の 5 担当はすへで向市にある。 所員は合計約140名に及んでいる。

ウラン浱縮研究所は宫崎県日向市細島の日向鹳に臨 んた社有地に位居する。面積約 $10,000 \mathrm{~m}^{2}$ 數地に，用 役付帯設備, 合庫を付属して濃縮研究設備建屋および 研究関連建屋が配固されている。2つの建屋の5ち， 前者はモデルプラントを収容し，後者にはヘンンチスケ 一ルの連続湿縮装置, 分析研究室, 事務室等がある(写 真 1 )。また，この數地に膦接して展示館があり，化 学法ウラン浩縮技術およひ濃縮ウランに関する外来見 学者の理解に供している。

\section{1. 基薄研究}

すでに研究所全体としては，ベンチ濃縮装置での実 用的プロセスの開発研究，モデルブラントでの濃縮実 証試匰の段階にあり，基礎研究は終了しつつある。開 発研究担当の研究す，1つはこれまでに築いた濃縮理 論と集積した基礎研究データに基づき，ペンチ濃樎装 固の運転結果を解析することに移っている。る51つ は吸着剂の製造であり，製品はペンチ，モデルの各濃 樎装直に供給されている。

これまでの化学法ウラン浱縮技術の開発において， 基礎研究の成果は影著であるといえよう。

（1）米国原子力委員会が，1972年のウラン濃縮特 別委員会で，3\%ウラン湦縮到達時間を約500年 と見棈っていた化学交換法をその 1,000 倍以 上に高速化することに成功した。

(2) フランス等で研究されながら失敗に帰したウ ラン吸着帯の安定な閉这め技術を開発した。

（3）最近の成果として，逆反応を利用して失活酸 化・遷元剤の濃縮塔内“自己賦活”を実現した。 このよらな成果は，外国に範を求めることができな い化学交換法を自らの創意で推進する原動力となり， 当所の誇りとする技術である。このほかに，分離技術 関連としては，酸化還元クロマトグラフィーによる濃 縮理諭の確立, 分離性能のシミェレーション予測, 分離 系の定常ハンド化, 湿縮塔数の少塔化が挙げられる。 自己賦活技術により，再生部に送るぺき失活した酸化・ 還元阂の負荷量は大幅に軽減し得るので，化学交換法 は本算的な低動力の特徽に加え一段と省エネルギープ ロセスに改良されよらとしている。

また、このような化学法の開発を支えてきたもら1 つの技術は，吸着剤の物理的,化学的設計とそれを実 現した合成技術とである。これまでに開発した吸着成 は, 高速浱樎, 高酎性, 自己賦活能および高剛性を併わ

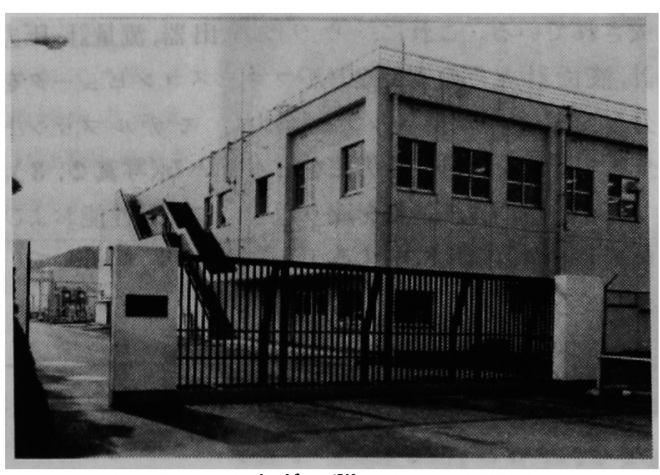

写木 1 斫究所正門と矿究関連建屋 


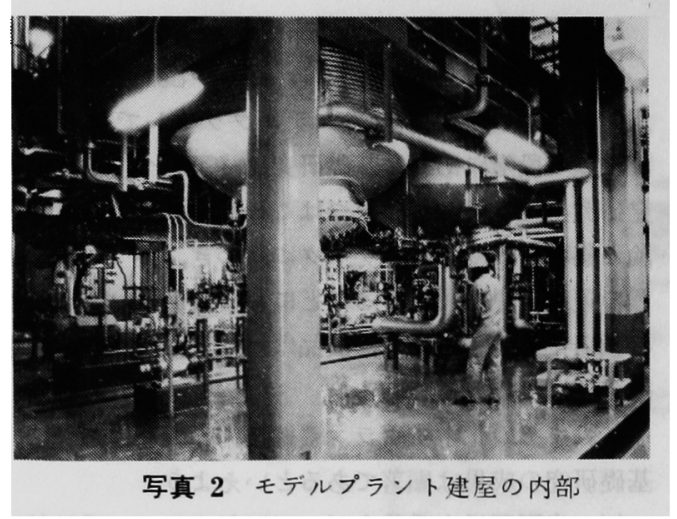

せ持っており，分離技術の進歩と相互補完的に生み出 されてきた。

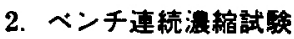

装置の完成以来，濃縮試験を繰り返してきたが，中 でも昭和57年および59年にそれぞれ小型および中型べ ンチ浱縮装置の長期連㓍運転( $3 \sim 4$ 力月)によって, ベッド長 $12 \mathrm{~m}$ の規模で㭠続的なウラン涨樎に成功し， 基礎研究で立てられた灙縮理諭が明確に実証された。

現在の課題は，濃縮効率を更に向上させること，濃 縮量を增大させること，洏樎に要するェネルギー量を 減らすことである。そのために，スーバー法と呼称さ れる条件での運転試駼を累施し、データの集皘,解析 を進めている。

\section{3. モテルブラントの実証運転}

モデルブラントの完成以降重ねてきた予備試験が終 了し，昨61年末よりウラン実液を用いた運転を開始し た。本装置は，(1)渻縮塔を中心に塔の上下両部に配し た自動切換ハルブ，送液配管からなる濃縮部，(2)酸化 タンク, 還元タンクを中心に送液ポンプ,配管からなる 再生部，(3)フィート液，浱縮液，減損液を収容する各夕 ンクを中心にフィード夜供給用ポンプ, 自動切換バル ブ，配管からなる供給・回収部，の3 部から基本的に鸼 成されている。これに，ウラン检出器,流量計,王力 計，液面計とその制御機器がプロセスコンピュータを 介してポンプ,切換:ルブと結ばれ，モデルプラント 全体の運転を制御する方法をとっている(写交 2, 3)。

現在，短期連続運転を繰り返しつつ濃縮性能および システムの信頼珄に咸するデータを収集,解析してい、 るところである。

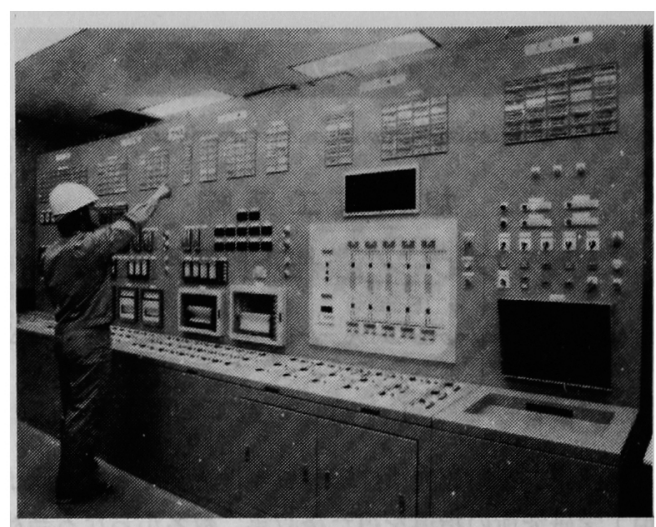

写真 3 モデルプラントの操作制御パネル

\section{III.むすび}

当研究所の研究は，国庫補助を受けているとはい え，ウラン浇縮とい5国策的な技術の開発を一民間企 業か進めている点でる，フランスの化学法を含めて他 に対応する実用化研究が見られない点からも，特異な 立場にあるとい之よら。しかし，原子力関係各位と同 様，われわれも原子力発電が将来のエネルギー供給の 主力となることを倍じ，またこの研究が近い将来，実 用化といら形で人々に貢献できることを念じつつ日夜 研究に勤しんでいる次第である。

(ウラン䙵縮研究所 武田邦彦)

（1987年 3 月27日 受 理）

「研究所船介シリース」は，(1)日立・エネ研，(2)日揮·大洗七 ンタ, (3)三菱原子力・大宮研, (4)東芝・原技研, (5)三蕧金属・中 研; 那珂七ン夕，(6)東電·原研，(7)住友金属·中央技研，8清水 建設·技研，(9石川島播磨·技研，(19)神戸製銅·材料研; 機械 研, (19原子力事業·総合研, (12)富士電機総合研, (13川崎重工・

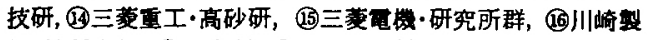

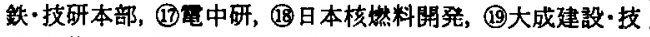
研, (20)住友金属鉱山·東海式唋所，(21大林組·技研，(22)工開研，

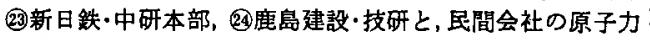
関係研究所を紹介しております(27[6〜12], 28[1～12], 29 $[1 \sim 5])$ 。

本号(26)後には，(26)関電，(27日本銅管，(28日立造船，(28) 立・日立研，(30会村組，(31)竹中工務店，……連载の予定であ ります。 記事揭载こ希至の向きはお申出で下さい。一投稿歡迎一 